
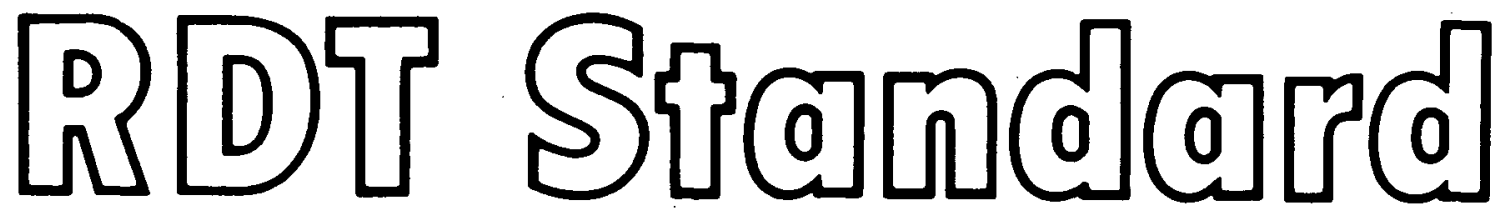

\title{
AUSTENITIC STAINLESS STEEL \\ HEXAGONAL DUCT TUBES \\ FOR CORE COMPONENTS \\ AND ASSEMBLIES
}

\section{MAY 1976}

Any further distribution by any holder of this document or of the data therein to third parties representing foreign interests, foreign governments, foreign companies, and foreign subsidiaries or foreign divisions of U.S. companies should be coordinated with the Director, Division of Reactor Development and Demonstration, U.S. Energy Research and Development Administration.

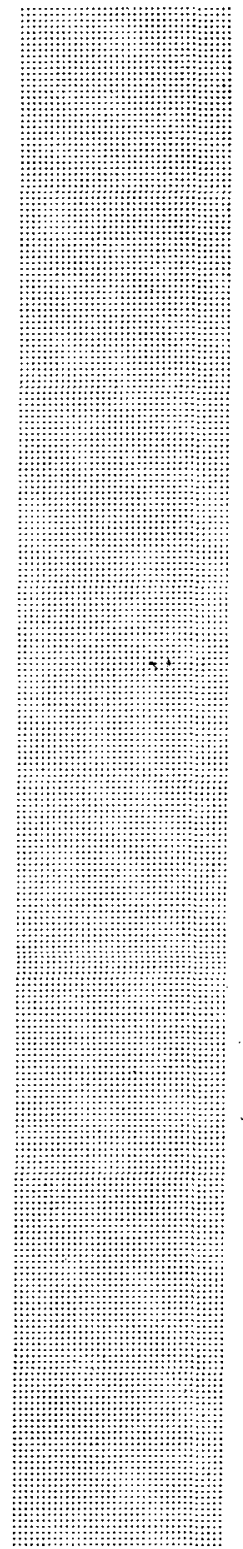




\section{DISCLAIMER}

This report was prepared as an account of work sponsored by an agency of the United States Government. Neither the United States Government nor any agency Thereof, nor any of their employees, makes any warranty, express or implied, or assumes any legal liability or responsibility for the accuracy, completeness, or usefulness of any information, apparatus, product, or process disclosed, or represents that its use would not infringe privately owned rights. Reference herein to any specific commercial product, process, or service by trade name, trademark, manufacturer, or otherwise does not necessarily constitute or imply its endorsement, recommendation, or favoring by the United States Government or any agency thereof. The views and opinions of authors expressed herein do not necessarily state or reflect those of the United States Government or any agency thereof. 


\section{DISCLAIMER}

Portions of this document may be illegible in electronic image products. Images are produced from the best available original document. 
Send copy and distribution inquiries to:

RDT Standards Office

Oak Ridge National Laboratory

Building 1000, Room 138-A

P. O. Box $X$

Oak Ridge, Tennessee $\mathbf{3 7 8 3 0}$

Printed in the United States of America

USERDA Technical Information Center; Oak Ridge, Tennessee 


\section{FOREWORD}

This standard supersedes the December 1971 issue of RDT E 6-20T and incorporates those changes to that issue of the standard that were approved and published as Amendment 1 and those changes that were approved for publication in this revision. The changes are identified by the following marginal notations:

$\begin{array}{lll}\text { A1 } & \text { Amendment 1, March } 1973 \\ \text { C } & \text { Change approved May } 1976 \\ \text { D } & \text { Deletion approved May } 1976 \\ \text { N } & \text { Addition approved May } 1976\end{array}$

Editorial changes that were made during preparation of this revision are not identified. 


\section{RDT STANDARD}

U.S. ENERGY RESEARCH AND DEVELOPMENT ADMINISTRATION DIVISION OF REACTOR DEVELOPMENT AND DEMONSTRATION

$\begin{array}{ll}\text { RDT } & \text { E 6-20T } \\ \text { DATE } & \text { May } 1976 \\ \text { PAGE } & -i \quad \text { OF ii }\end{array}$

AUSTENITIC STAINLESS STEEL HEXAGONAL DUCT TUBES FOR CORE COMPONENTS AND ASSEMBLIES

\section{TABLE OF CONTENTS}

\section{$\underline{\text { Page }}$}

1. SCOPE 1

1.1 Application 1

1.2 Definitions 1

2. APPLICABLE DOCUMENTS 2

2.1 RDT Standards 2

2.2 Military Specifications 2

2.3 American National Standards (ANSI) 2

2.4 American Society of Mechanical Engineers (ASME) Publications 2

2.5 American Society for Testing and Materials (ASTM) 2 $\begin{array}{ll}\text { Publications } & 2 \\ & 3\end{array}$

$\begin{array}{lll}2.6 & \text { Drawings } & 3 \\ 2.7 & \text { Other Documents } & 3\end{array}$

3. TECANILAL REQJIREMENTS 3

3.1 Material Reciuirements 3

3.2 Mechanical Properties 4

3.3 Nondestructive Examination Requirements 5

3.4 Metallcgraphic Requirements 5

3.5 Surface Requirements 5

3.6 Duct Tube Dimensions 6

3.7 Processes $\quad 7$

3.8 Repair and Rework 8

3.9 Archive Samples $\quad 8$

4. QUALITY ASSURANCE REQUIREMENTS 8

4.1 Quality Assurance Program Requirements 8

4.2 Quality Assurance Documentation 8

4.3 Records 8

4.4 Responsibility 9

4.5 Inspection Requirements 9

4.6 Purchaser's Inspection 9

4.7 Measuring and Test Equipment 9

$\begin{array}{ll}4.8 & \text { Determination of Compliance and Data Recording for } \\ \text { Inspection and Test } & 19\end{array}$ 
RDT

E 6-20T

PAGE

ii

Page

5. PREPARATION FOR DELIVERY

19

5.1 Packaging

5.2 Shipping Containers

5.3 Marking

19

19

20

6. NOTES AND ORDERING DATA CHECKLIST

20

6.1 Intended Use

20

6.2 Ordering Data Check1ist

20 
U.S. ENERGY RESEARCH AND DEVELOPMENT ADMINISTRATION

DATE May 1976

DIVISION OF REACTOR DEVELOPMENT AND DEMONSTRATION

PAGE

AUSTENITIC STAINLESS STEEL HEXAGONAL DUCT TUBES FOR CORE COMPONENTS AND ASSEMBLIES

1. SCOPE

This standard establishes the requirements for austenitic stainless steel seamless hexagonal duct tubes for fuel, control rod, and other core component assemblies.

1.1 Application. This standard applies to annealed or cold worked seamless duct tubes of 3 to 6 inch ( 76 to $152 \mathrm{~mm}$ ) outside dimension and having up to 0.250 inch $(6.35 \mathrm{~mm})$ wall thickness.

\subsection{Definitions.}

1.2.1 Billet. An ingot or section of an ingot that has been hot worked by forging, rolling, or extrusion.

1.2.2 Control Rod Duct. A tubular structure which positions and supports an array of absorber pins in the reactor core and consists of a duct tube and end fittings all joined to form an integral assembly.

1.2.3 Duct Tube. The hexagonal tube portion of the fuel duct or control rod duct with load pads, exclusive of hard surfacing, which encloses the fuel pin or absorber pin array and provides the channel for the primary coolant.

1.2.4 Duct Tube Blank. A seamless tube of circular cross section from which the duct tubes are formed.

1.2.5 Fuel Duct. A tubular structure which positions and supports an array of driver fuel pins in the reactor core and consists of a duct tube and end fittings all joined to form an integral assembly.

\subsubsection{Heat. A single, homogeneous melt.}

1.2.7 Ingot. A casting intended for subsequent working such as forging, rolling, extrusion, or drawing.

1.2.8 Lot. The product of one heat of material annealed under identical annealing parameters.

1.2.9 Repair. Utilization of operations that are not a part of the normal fabrication procedure to restore an item to an acceptable condition.

1.2.10 Rework. Utilization of operations that are part of the normal fabrication procedure to restore an item to an acceptable condition. 
1.2.11 Temper Point. That point in the tube fabrication to process immediately following a final anneal and preceding a final cold working operation. Dimensions are established at this point that will assure the desired cold work in the final pass.

\section{APPLICABLE DOCUMENTS}

The following documents are a part of this standard to the extent specified in Sections 3 through 5 . The issue of a document in effect on the date of the invitation to bid, including any amendments or other published changes also in effect on that date, sha11 apply unless otherwise specified. Where this standard appears to conflict with the requirements of a reference document, such conflict shall be brought to the attention of the purchaser for resolution.

\subsection{RDT Standards.}

RDT F 2-2 Quality Assurance Program Requirements

RDT F 3-6T Nondestructive Examination

RDT F 3-15T Requirements for Inspection of Dimensional Characteristics | N

RDT F 5-1T Cleaning and Cleanliness Requirements for Nuclear Components

RDT F 7-2T Packaging, Packing, and Marking of Components for Shipment and Storage

RDT F 11-3T Analytical Chemistry Methods for Metallic Core Components |N

\subsection{Military Specifications.}

MIL-H-6875 Heat Treatment of Steels

\subsection{American National Standards (ANSI).}

ANSI B46.1 Surface Texture

\subsection{American Society of Mechanical Engineers (ASME) Publications.}

Boiler and Pressure Vessel Code

Section III Nuclear Power Plant Components

2.5 American Society for Testing and Materials (ASTM) Publications.

ASTM A 262 Susceptibility to Intergranular Attack in Stainless Steels |A1

ASTM A 370 Mechanical Testing of Stee1 Products 
ASTM A 450 Carbon, Ferritic Alloy, and Austenitic Alloy Steel Tubes

ASTM E $3 \quad$ Metallographic Specimens

ASTM E $8 \quad$ Tension Testing of Metallic Materials

ASTM E 21 Elevated Temperature Tension Tests of Metallic Materials

ASTM E 29 Indicating Which Places of Figures Are to Be Considered Significant in Specified Limiting Values

ASTM E 45 Inclusion Content of Steel

ASTM E 92 Vickers Hardness of Metallic Materials

ASTM E 112 Average Grain Size of Metals

ASTM E 113 U1trasonic Testing by the Resonance Method Data.

2.6 Drawings. Drawings shall be as specified in the Ordering

2.7 Other Documents. Other documents shall be as specified in the Ordering Data.

\section{TECHNICAL REQUIREMENTS}

\subsection{Material Requirements.}

3.1.1 Chemical Composition. Finished ducts tubes of Type 316 stainless steel shall conform to the chemical composition requirements of Table 1. Finished duct tubes of other material types $(304,321,348)$ shall be as specified in the ordering Data. Ingots shall be analyzed and the analysis results shall be reported for information prior to use for fabrication.

3.1.2 Grain Size. The average grain size of duct material from any lot following final anneal and prior to cold working shall be 4 to 7 as determined by ASTM E 112, reference Plate II and shall exhibit no evidence of duplex structure.

3.1.3 Corrosion Resistance. Finished duct tubes shall not show susceptibility to intergranular attack when tested in accordance with ASTM A 262, Practice E. Evidence of cracking or intergranular at tack sha11 be cause for rejection.

\subsection{Mechanical Properties.}

3.2.1 Tensile Properties. Longitudinal properties of duct tubes in the 20 percent cold worked condition shall meet the requirements of Table 2. Longitudina1 properties of duct tubes in the 
Table 1. Alloy Composition Limits for Type 316 Stainless Steel

\begin{tabular}{ll}
\hline Element & Percentage \\
\hline Chromium & 17.0 to 18.0 \\
Nickel & 13.0 to 14.0 \\
Carbon & 0.040 to 0.060 \\
Molybdenum & 2.00 to 3.00 \\
Manganese & 1.50 to 2.00 \\
Nitrogen & $0.010 \max$. \\
Aluminum & $0.050 \max$. \\
Arsenic & $0.030 \max$. \\
Boron & $0.0010 \max$. \\
Cobalt & $0.050 \max$. \\
Columbium & $0.050 \max$. \\
Copper & $0.10 \max$. \\
Phosphorus & $0.020 \max$. \\
Silicon & $0.75 \max$. \\
Sulfur & $0.010 \max$. \\
Tantalum & $0.020 \max$. \\
Vanadium & $0.20 \max$. \\
Iron & Balance \\
\hline
\end{tabular}

Table 2. Tensile Property Requirements For Type 316 Stainless Steel

Material Temperature Tensile Strength Yield Strength Min. Elongation in Condition

${ }^{\circ} \mathrm{F} \quad \mathrm{ksi}$

$\left({ }^{\circ} \mathrm{C}\right)$ (MPa)

$0.2 \%$ offset $2 \mathrm{in.}(51 \mathrm{~mm})$

ksi

(MPa)

$\begin{array}{llrcr}\begin{array}{l}20 \% \text { Cold } \\ \text { Worked }\end{array} & \text { Room } & \begin{array}{r}100 \text { to } 130 \\ (689 \text { to } 896)\end{array} & \begin{array}{c}85 \text { to } 115 \\ (586 \text { to } 793)\end{array} & 15 \\ \begin{array}{l}\text { 20\% Cold } \\ \text { Worked }\end{array} & 1000 & 75 \text { to } 100 & 60 \text { to } 90 & 7 \\ & (538) & (517 \text { to } 689) & (414 \text { to } 620) & \end{array}$

temper point condition shall be reported for information only. The tensile properties of finished tubes of other material types, other levels of cold work, or both, shall be as specified in the Ordering Data.

3.2.2 Hardness. The Vickers hardness values on samples of finished duct tubes taken across the wall thickness of a flat and a corner shall not exceed the values specified in the Ordering Data. 


\subsection{Nondestructive Examination Requirements.}

3.3.1 Penetrant Examination, Finished Dučts. Interior and exterior surfaces of finished duct tubes shall be free of defects as shown by fluorescent penetrant examination specified in 4.5. (See Table 4, Item 6.)

3.3.2 U1trasonic Examination. Finished duct tube blanks sha11 be ultrasonically examined as specified in 4.5. (See Table 4, Item 7.)

\subsection{Metallographic Requirements.}

3.4.1 Inclusions. The inclusion content of billets shall not exceed the limits set forth in Table 3 when determined as described in ASTM E 45, Microscope Method D. A maximum of 10 percent of the fields may show inclusions at the next higher density to that specified and a maximum of 1 percent of the fields may show inclusions at the second higher density.

Table 3. Inclusion Content Limits

Inclusion Type (ASTM E 45)

\begin{tabular}{ccccccccc}
\hline Sulfide & Type (A) & Alumina & Type (B) & Silicate & Type (C) & Globular & Oxides (D) \\
\hline Thin & Thick & Thin & Thick & Thin & Thick & Thin & Thick \\
\hline 1 & 1 & 1 & 1 & 1 & 1 & 1 & 1 \\
\hline
\end{tabular}

3.4.2 Intergranular Attack. Finished duct tubes shall be metallographically examined to verify freedom from intergranular attack.

3.4.3 Carbide Precipitation. Finished duct tubes shall be metallographically examined as specified in 4.5. [See Table 4, Item 8(c)] to verify freedom from visible carbide precipitation at grain boundaries after heat treatment as specified in 3.7 .1 (d).

\subsection{Surface Requirements.}

3.5.1 Surface Condition. The finished duct tubes shall be free of visible oxide, scale, splits, laps, cracks, seams, inclusions, and other defects.

3.5.2 Surface Roughness. Al1 surfaces of finished duct tubes shall meet or exceed the requirements in the Ordering Data.

3.5.3 Surface Marring. Finished duct tubes shall be free of scratches, dents, or mars except of the dimensions and types listed 
below. Surface imperfections such as handling marks, light mandrel, and die or roll marks will not be considered as injurious defects provided they are less than 0.002 inch $(0.05 \mathrm{~mm})$ in depth, and do not reduce the wall thickness to less than the minimum specified in the Ordering Data. Corner defects on the outside diameter and the inside diameter shall be limited to $1 / 2$ inch $(13 \mathrm{~mm})$ in length and less than 0.002 inch $(0.05 \mathrm{~mm})$ in depth. Removal of such defects by grinding, buffing or polishing is considered a repair subject to requirements of 3.8 , but is permitted provided all other dimensions and surface finish requirements are maintained. Polishing of duct tubes and duct tube blanks solely to improve surface finish is not construed as a repair or rework operation. The bottom of these defects shall be visible, rounded, and well faired in as confirmed by visual inspection as specified in 4.5 (see Table 4, Item 9) and by penetrant examination as specified in 4.5. (See Table 4, Item 6.)

3.5.4 Residual Chloride and Fluoride. The amount of residual chloride and fluoride on duct tubes after final inspection shall each be less than $0.5 \mathrm{\mu g} / \mathrm{in} .^{2}\left(0.8 \mathrm{mg} / \mathrm{m}^{2}\right)$ of duct tube surface.

\subsubsection{Cleanliness. All cleaning procedures and techniques} sha11 be in accordance with RDT F 5-1. Finished duct tubes shall be free of residual iron, other metallic particles, oil, grease, lubricants, residual cleaning compounds, dirt, chips, and all other extraneous material, and sha1l be cleaned in nitric acid after final inspection tests and just prior to packaging by the process specified below.

a. Precleaning. Components shall be precleaned with a approved soak cleaner and shall be thoroughly rinsed with water before immersion in the nitric acid solution.

b. Final cleaning. Components shall be treated with nitric acid prepared as follows:

1. Grade

2. Concentration

3. Temperature

4. Time
Reagent grade

10 to 14 percent

Room

10 min., or until free surface iron has been removed

c. Rinsing. Components shall be thoroughly rinsed in water, not exceeding $185^{\circ} \mathrm{F}\left(85^{\circ} \mathrm{C}\right)$, meeting the requirements for Grade $B$ as specified in RDT F 5-1.

d. Drying. Components sha1l be dried in air at a temperature not. exceeding $185^{\circ} \mathrm{F}\left(85^{\circ} \mathrm{C}\right)$.

e. Contact Preservatives. Contact preservatives shall not be used.

3.6 Duct Tube Dimensions. Duct tubes shall meet the dimensional requirements specified in the Ordering Data. 


\subsection{Processes.}

\subsubsection{Manufacture.}

a. Melting. The steel shall be made by double vacuum melting process, using virgin materials only with no scrap additions. Material melted to this standard and recovered from the double vacuum melting process shall be acceptable for remelting. The process shall consist of a vacuum induction melt followed by a consumable electrode vacuum arc remelt. Any proposed alternative to this melting process shall require written approval. Additions of rare earth during melting are prohibited.

b. Tube Making. Duct tubes shall be made by an approved seamless process.

c. Special Handling. Handling methods shall prevent duct tube-totube contact during processing, cleaning, and storage and shall be consistent with the preservation of a mar-free surface finish. Special handling procedures shall be provided to maintain the identity of duct tubes at all times. The proposed handling methods shall be submitted for approval prior to use.

d. Heat Treating. Prior to any final cold working operation, the duct tubes sha11 be bright hydrogen-annealed. Duct tubes required in the annealed condition shall be bright hydrogen-annealed. The dew point of the gas at the hydrogen inlet shall be less than $-80^{\circ} \mathrm{F}\left(-62^{\circ} \mathrm{C}\right)$, and the dew point of the hydrogen at exit shall not exceed $-40^{\circ} \mathrm{F}\left(-40^{\circ} \mathrm{C}\right)$. The temperature and time shall be selected to ensure carbide solution and proper grain size as described in 3.1.2. Cooling shall be at a rate rapid enough to avoid visible carbide precipitation as described in 3.4.3. Alternate annealing processes that do not result in intergranular attack may be used with prior approval. Cold worked tubes shall be cold worked to finished size and delivered without further heat treatment.

e. Cleanliness During Manufacture. Duct tubes shall be cleaned prior to each annealing operation and after each cutting operation prior to further reduction. Only fresh lubricants shall be used and they shall be readily removable by commercial cleaning agents. All lubricants shall be removed prior to any heat treatment.

f. Cold Work. Duct tubes shall be cold worked as specified in the Ordering Data subsequent to the final bright anneal. Percent cold work shall be based upon reduction in the cross-sectional area. Percent cold work determined by reduction in transverse area shall be calculated using Equation 1.

$$
C_{w}=\frac{A_{1}-A_{2}}{A_{1}} \times 100
$$


where

$$
\begin{aligned}
& \mathrm{Cw}=\text { percent cold work } \\
& \mathrm{A}_{1}=\text { tubing cross-sectional area prior to final cold work } \\
& \mathrm{A}_{2}=\text { tubing cross-sectional area after final cold work. }
\end{aligned}
$$

The cold working procedure and method for measuring percent cold work shall be submitted for approval prior to use. The duct tubes shall have uniform cold work as produced by cold working hexagonal shaped stock to final hexagonal dimensions.

\subsubsection{Lotting. Duct tubes sha11 be lotted on the basis of} items of the same nominal dimensions produced from the same heat, processed consecutively, and annealed under identical parameters. Any sublotting shall be as specified in the Ordering Data.

3.7.3 Identification. Duct tubes shall be marked and processed in a manner that will ensure individual duct tube identity. Individual duct tubes shall be identified with a lot code, and each duct tube shall be assigned a sequential number as specified in the Ordering Data. The numbering system shall be designed to identify the supplier, lot, and tube number. Duct tubes shall be marked using an electrolytic etch. The electrolytic etch technique shall be submitted for approval.

3.8 Repair and Rework. Repaired and reworked duct tubes shall meet the requirements of this standard. Repair and rework shall be permitted only after prior approval.

3.9 Archive Samples. Archive samples shall be supplied as specified in the Ordering Data.

4.1 Quality Assurance Program Requirements. The supplier sha11 plan, establish, implement, and maintain a documented quality assurance program that fulfills all requirements of Sections $1,2,4,5$, and 8 of RDT F 2-2 and any additional quality assurance requirements of the Ordering Data.

4.2 Quality Assurance Documentation. The supplier is responsible for the preparation of all quality assurance documentation required by the applicable sections of RDT F 2-2. The purchaser will specify the documents required and submittal times in the Ordering Data. The granting of process or procedural approvals by the purchaser shall not be construed to relieve the supplier in any way or to any extent from the full responsibility for delivering items conforming with all requirements of this standard and the Ordering Data.

4.3 Records. Records shall be maintained for each duct tube lot which are traceable to feed materials and heat numbers and showing 
complete fabrication and sequence of operations from melt through drawing, annealing, and cold work. Records shall include the number and type of forming operations, the sequence of such operations indicating the duct tube size at each stage, the sequence of annealing operations detailing the time, temperature, atmosphere of the annealing cycle, and grain size of annealed material. This information shall be supplied with the test reports on all delivered duct tubes.

4.4 Responsibility. Unless otherwise specified, the supplier shall be responsible for the performance of all tests and inspections required prior to submission of any item for acceptance. The performance of such tests and inspections does not limit the right of the purchaser to conduct such other tests and inspections as deemed necessary to assure that all items are in conformance with all requirements of this standard and the Ordering Data. Except as otherwise specified, the supplier may use either his own or any commercial laboratory acceptable to the purchaser. Records of all tests and examinations shall be kept complete and available to the purchaser.

4.5 Inspection Requirements. Inspection requirements are listed in Table 4. Where "lot qualification" is listed as the inspection plan or type, the lot shall be accepted only when all of the required number of samples meet the referenced requirements. Reference test methods are the preferred methods. Actual methods used shall be equal to or better than the methods referenced and shall be approved by the purchaser. Where 100 percent inspection for dimensional characterization is required, an acceptance criteria shall be established based upon the exhibited measurement error, which shall result in not more than 5 percent chance of accepting items deviating from the specified tolerance range by more than 10 percent.

Al1 metallurgical samples prepared for tests specified in Table 4, Items 2, 3, 4, 5, and 8 shall be submitted with the duct tubes. Each tested sample shall be identified with a number identical to the duct tube from which it was taken.

Where the method of gaging is not given in Table 4, Item 10, the proposed method of gaging shall be submitted for approval.

4.6 Purchaser's Inspection. The purchaser's representatives shall be provided, free of cost, all reasonable access to facilities to satisfy themselves that the material meets the requirements of this standard and the Ordering Data. Duct tubes which are released by the purchaser's inspector at the place of manufacture, but are subsequently shown through tests or analysis not to conform with this standard and the Ordering Data, are subject to rejection.

\subsection{Measuring and Test Equipment.}

4.7.1 Environmental Controls. Measuring and test equipment and measurement standards shall be calibrated and utilized in an environment 
Table 4. Quality Conformance Inspection

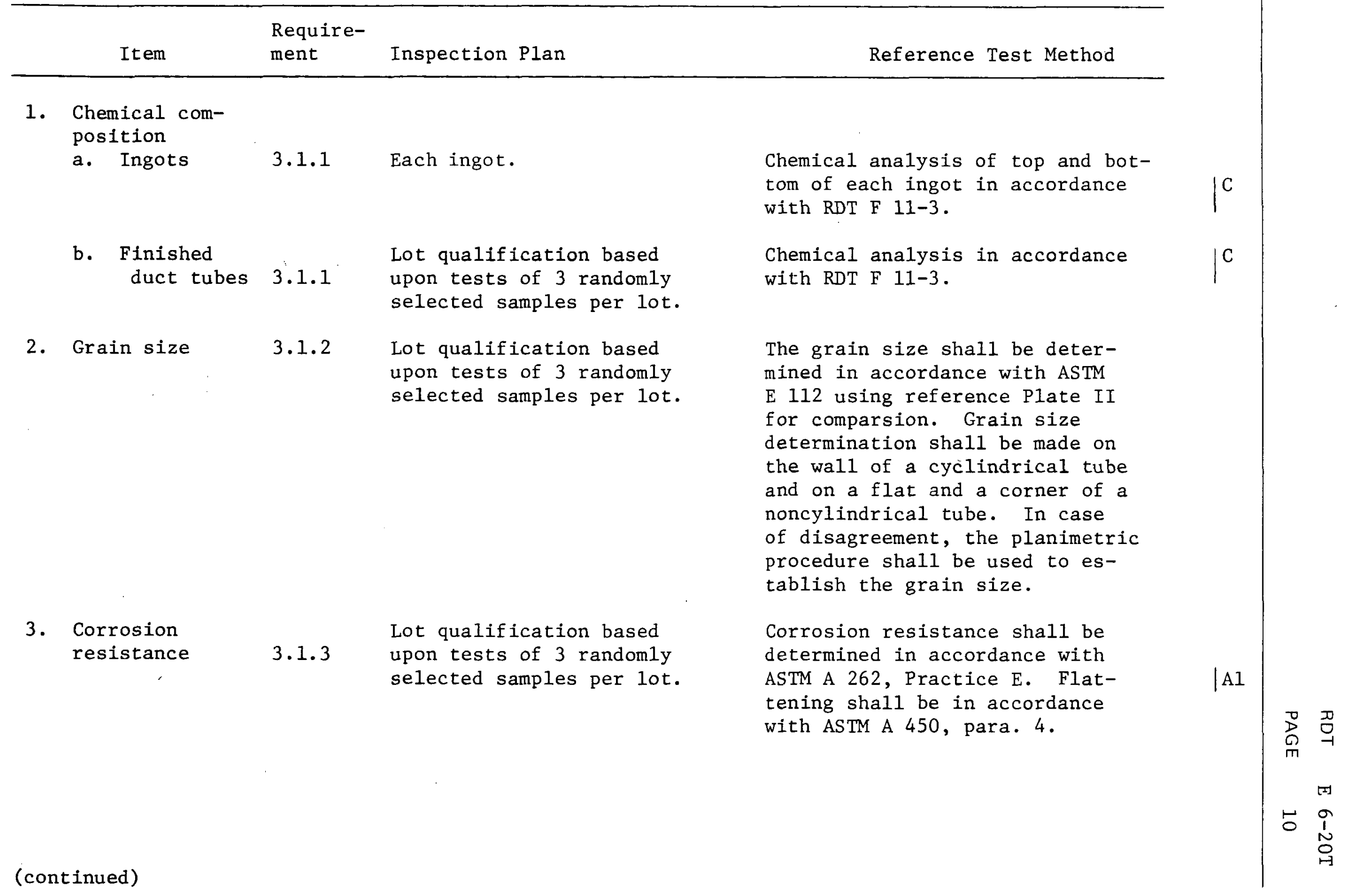


Table 4. Quality Conformance Inspection (Cont'd)

\begin{tabular}{cll}
\hline Item & $\begin{array}{l}\text { Require- } \\
\text { ment }\end{array}$ & Inspection Plan \\
\hline
\end{tabular}

4. Mechanical

properties

a. Room temp. 3.2.1

tensile test

Lot qualification based upon tests of 3 randomly selected samples per lot. (Variables data to be reported).

b. $1000^{\circ} \mathrm{F}$

$\left(528^{\circ} \mathrm{C}\right)$

tensile

test

\section{2 .1}

Lot qualification based upon tests of 3 randomly selected samples per lot. (Variables data to be reported).
Room temperature tensile properties shall be determined using methods described in ASTM A 370. Gage length shall be consistent with ASTM E 8. The strain rate shall be 0.05 in./(in.) (min) $[0.05 \mathrm{~mm} /(\mathrm{mm})(\mathrm{min})]$ until the yield point is reached. In determining the tensile strength, the rate of separation of the heads under load shall not exceed $1 / 2$ in./(in.) (min) $[1 / 2 \mathrm{~mm} /(\mathrm{mm})(\mathrm{min})]$ of gage length.

Elevated temperature tensile testing shall comply with ASTM E 21. Gage length sha11 be consistent with ASTM E 8. The strain rate shall be 0.05 in./(in.) (min.) $[0.05 \mathrm{~mm} /(\mathrm{mm})(\mathrm{min})]$ until the yield point is reached. In determining the tensile strength, the rate of separation of the heads under load shall not exceed $1 / 2 \mathrm{in.} /$ (in.) (min) $[1 / 2 \mathrm{~mm} /(\mathrm{mm})$ (min)] of gage length. 
Table 4. Quality Conformance Inspection (Cont'd)

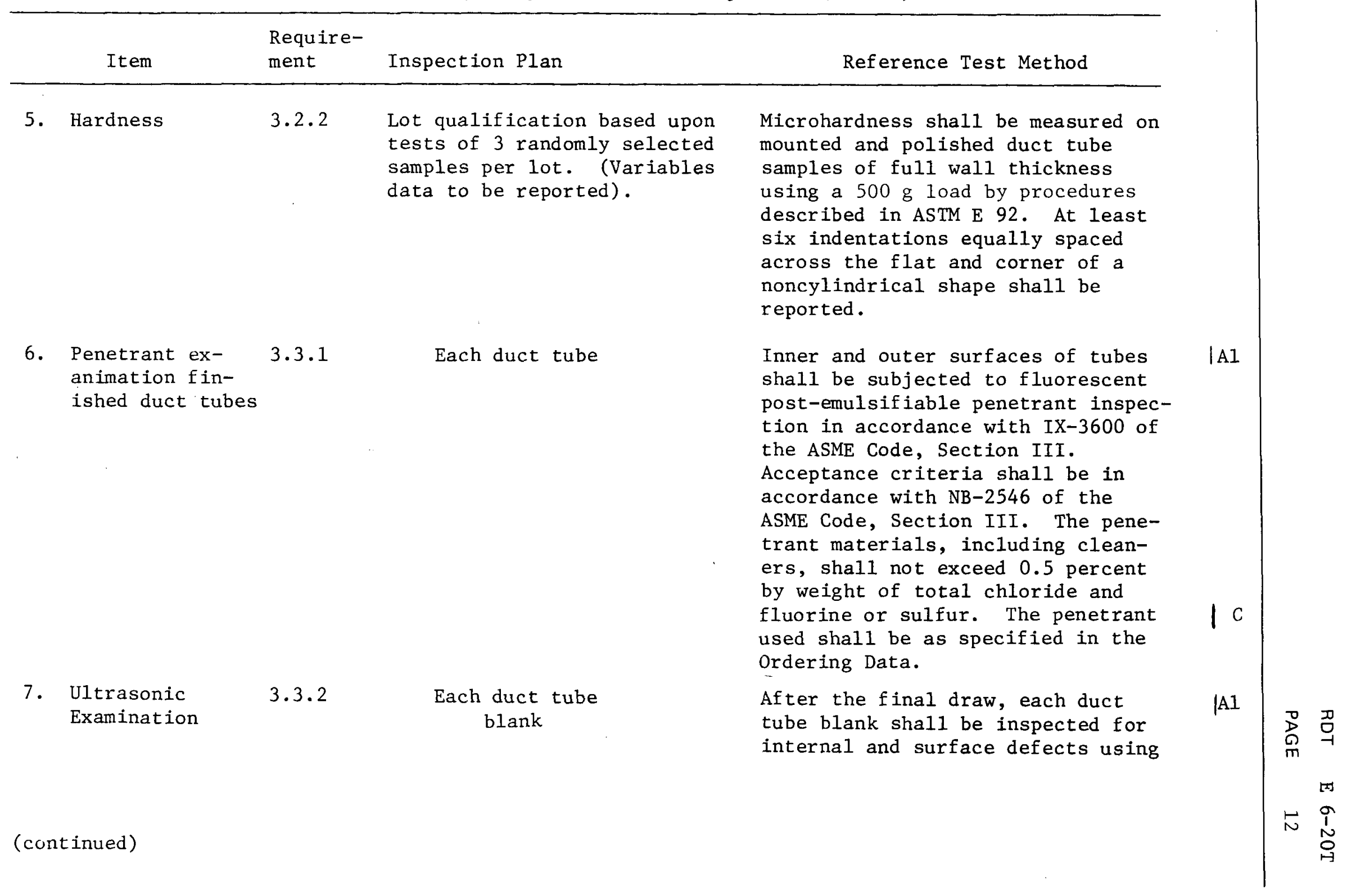


Table 4. Quality Conformance Inspection (Cont'd)

Require-

ment Inspection Plan

Reference Test Method

pulse-echo ultrasonic techniques in accordance with RDT F 3-6.

The ultrasound shall be trans-

mitted in both circumferential

directions with pulse-echo type

instruments and accessory equip-

ment capable of distinguishing

the reference notches of the

artifical standard described be-

low. Acceptance criteria for the

duct tube blank shall reflect the

observed inherent measurement

error and shall provide (with 95

percent confidence), for the re-

jection of a natural defect having a depth equal to 4 percent of the

wall thickness. A helical scan of the duct tube blank surface shall

be employed, and the speed of rotation and translation shall be maintained constant to within \pm 10 percent. The pitch of the feed helix shall be small enough to permit the signal from each reference notch to appear on at least four successive revolutions of the tube.

Notch standards for equipment calibration shall have the following

dimensions: 
Table 4. Quality Conformance Inspection (Cont'd)

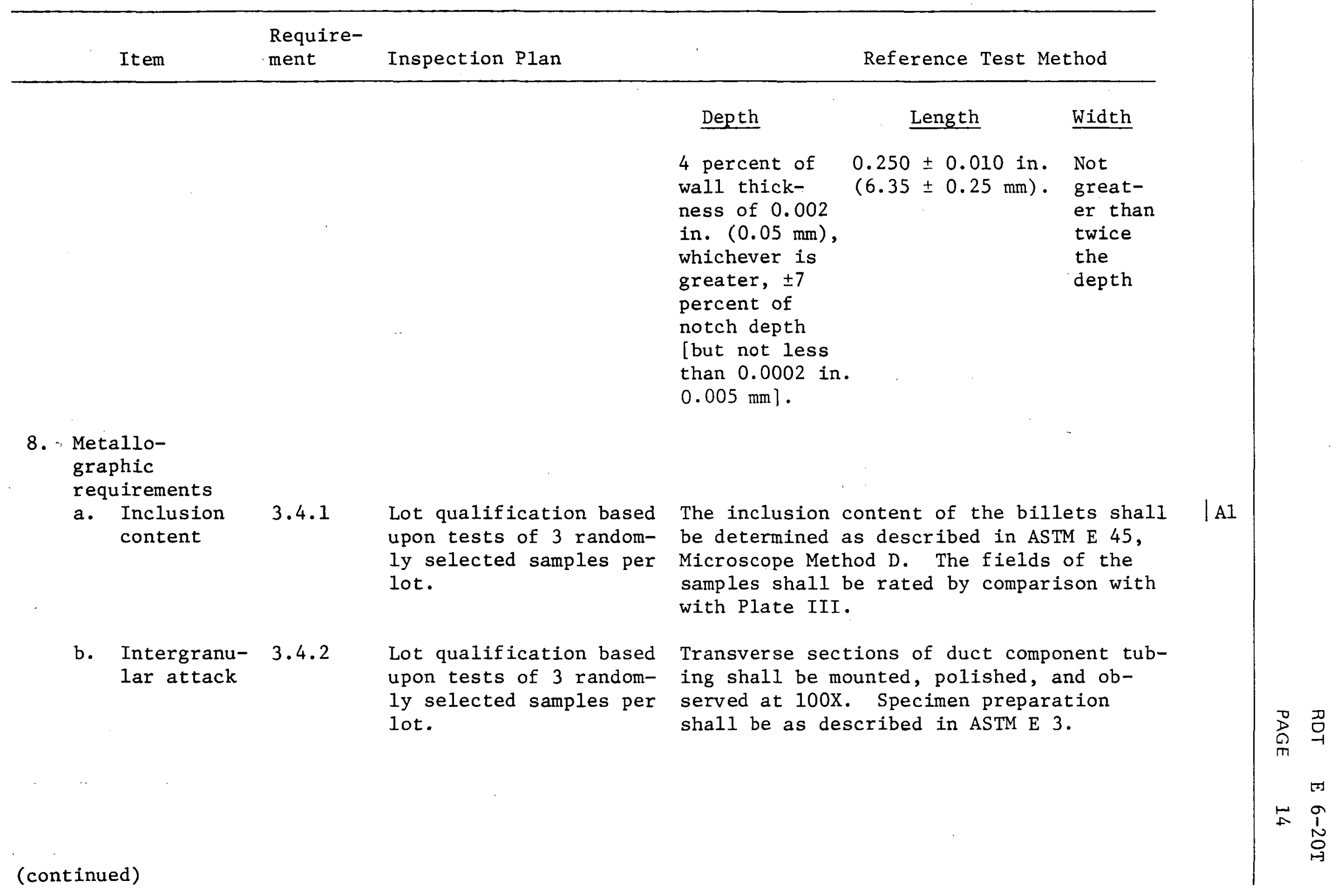


Table 4. Quality Conformance Inspection (Cont'd)

\begin{tabular}{|c|c|c|c|c|c|c|c|}
\hline & & Item & $\begin{array}{l}\text { Require- } \\
\text { ment }\end{array}$ & Inspection Plan & Reference Test Method & & \\
\hline & c. & $\begin{array}{l}\text { Carbide } \\
\text { precipita- } \\
\text { tion }\end{array}$ & 3.4 .3 & $\begin{array}{l}\text { Lot qualification based upon } \\
\text { tests of } 3 \text { randomly selected } \\
\text { samples per lot. }\end{array}$ & $\begin{array}{l}\text { Transverse sections of tubing } \\
\text { shall be mounted, polished, etch- } \\
\text { ed, and examined at } 500 x \text {. Speci- } \\
\text { men preparation shall be as des- } \\
\text { cribed in ASTM E } 3 \text {. The same } \\
\text { specimen used in examination for } \\
\text { intergranular attack in (b) above } \\
\text { may be used. }\end{array}$ & & \\
\hline \multirow[t]{4}{*}{9.} & \multicolumn{6}{|c|}{$\begin{array}{l}\text { Surface re- } \\
\text { quirements }\end{array}$} & \\
\hline & a. & $\begin{array}{l}\text { Surface } \\
\text { condition }\end{array}$ & 3.5 .1 & Each duct tube & $\begin{array}{l}\text { Visual examination of all sur- } \\
\text { faces. }\end{array}$ & $\mathrm{A} 1$ & \\
\hline & b. & $\begin{array}{l}\text { Surface } \\
\text { roughness }\end{array}$ & 3.5 .2 & Each duct tube & $\begin{array}{l}\text { The duct tubes shall be examined } \\
\text { visually on all surfaces and } \\
\text { compared with the applicable stan- } \\
\text { dards specified in ANSI B } 46.1 \text {. } \\
\text { Surface roughness measuring in- } \\
\text { struments may be used as a manu- } \\
\text { facturer's option as an alternate } \\
\text { method and shall be used in case } \\
\text { of disagreement. }\end{array}$ & Al & \\
\hline & $\mathrm{c}$ & $\begin{array}{l}\text { Surface } \\
\text { marring }\end{array}$ & 3.5 .3 & Each duct tube & $\begin{array}{l}\text { The duct tubes shall be examined } \\
\text { visually. Areas in question on } \\
\text { OD and ID with scratches or dents } \\
\text { shall be examined at 10x magnifi- } \\
\text { cation. Instruments for measur- } \\
\text { ing flaw depths shall be used in } \\
\text { case of disagreement. }\end{array}$ & Al & 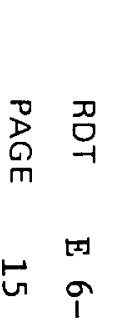 \\
\hline
\end{tabular}


Table 4. Quality Conformance Inspection (Cont'd)

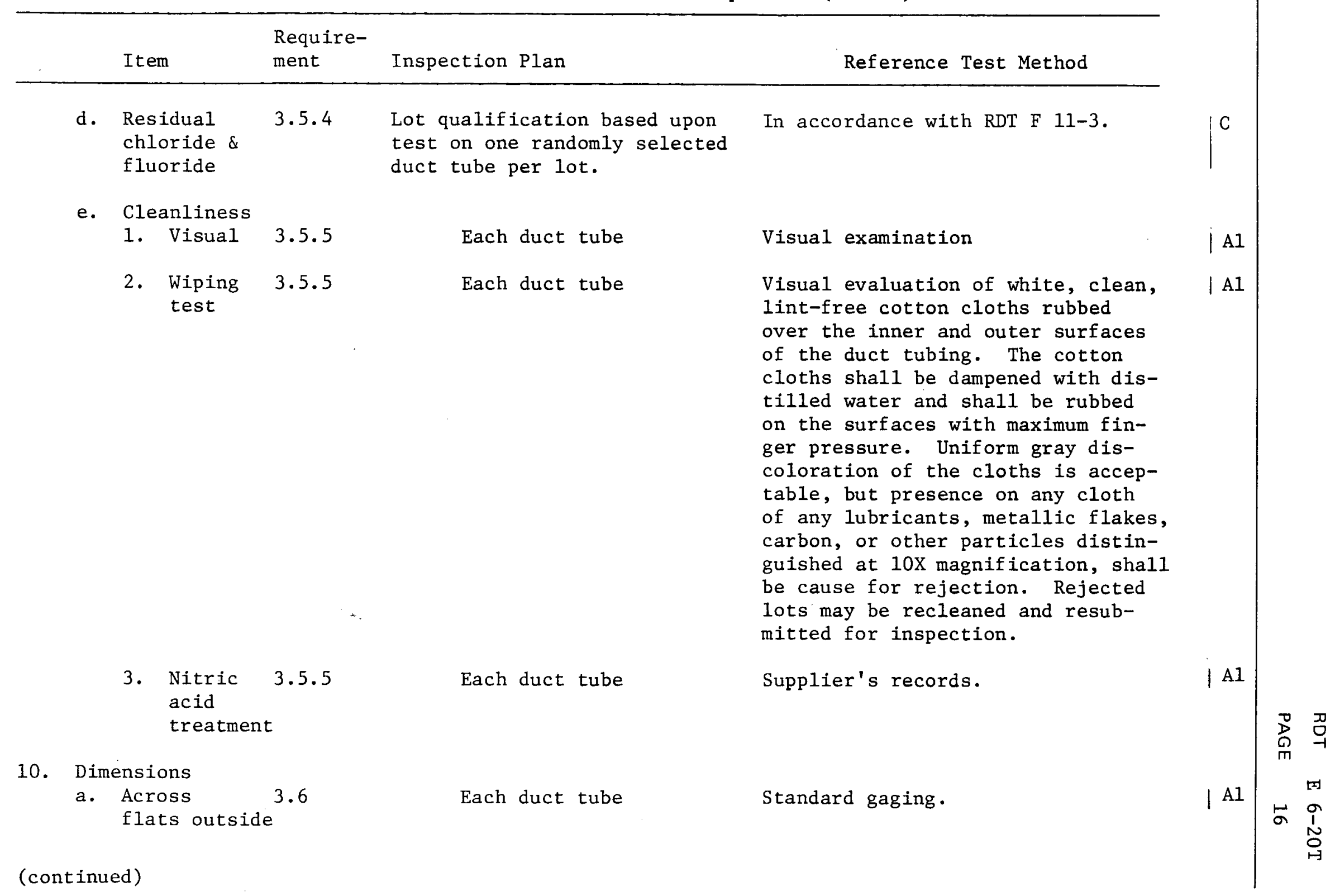


Table 4. Quality Conformance Inspection (Cont'd)

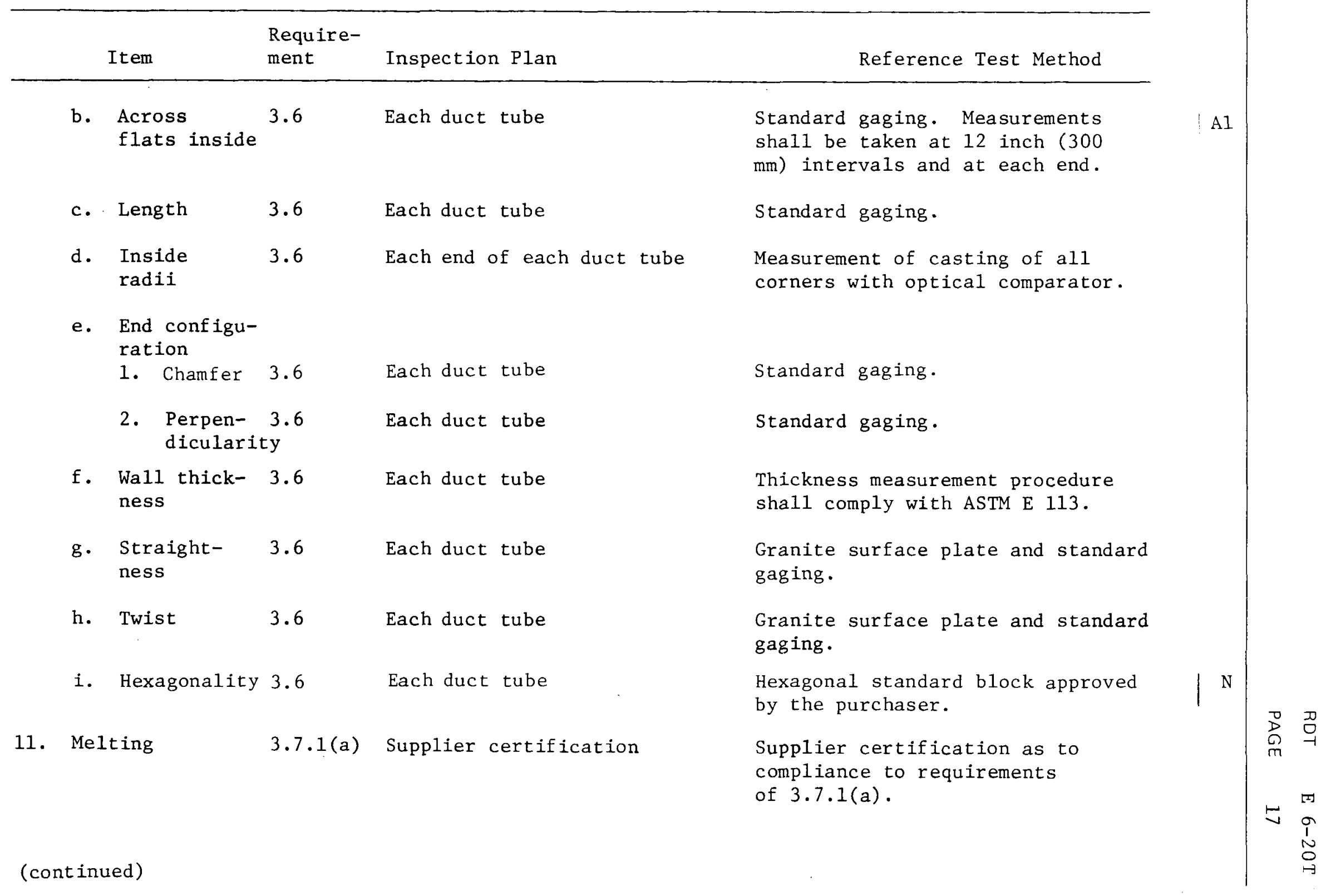


Table 4. Quality Conformance Inspection (Cont'd)

\begin{tabular}{|c|c|c|c|c|c|}
\hline & Item & $\begin{array}{l}\text { Require- } \\
\text { ment }\end{array}$ & Inspection Plan & Reference Test Method & \\
\hline 12. & Tubemaking & $3.7 .1(\mathrm{~b})$ & Supplier certification & $\begin{array}{l}\text { Supplier certification as to } \\
\text { compliance to requirements } \\
\text { of } 3.7 .1(\mathrm{~b}) \text {. }\end{array}$ & \\
\hline 13. & $\begin{array}{l}\text { Special } \\
\text { handling }\end{array}$ & $3.7 .1(c)$ & Supplier certification & Supplier's records. & \\
\hline 14. & Heat treatment & $3.7 .1(d)$ & Supplier certification & $\begin{array}{l}\text { The supplier's heat treating equipment } \\
\text { and temperature controlling devices } \\
\text { shall be calibrated in accordance with } \\
\text { MIL-H- } 6875 \text {. Dew points shall be deter- } \\
\text { mined by an Alnor "Dew Pointer" or } \\
\text { equivalent. }\end{array}$ & \\
\hline 15. & Cleanliness & $3.7 .1(\mathrm{e})$ & Supplier certification & Supplier's records. & \\
\hline 16. & Cold work & $3.7 .1(\mathrm{f})$ & $\begin{array}{l}\text { Lot qualification based } \\
\text { upon tests of } 3 \text { random- } \\
\text { ly selected samples per } \\
\text { lot. (Variables data to } \\
\text { be reported). }\end{array}$ & $\begin{array}{l}\text { Measure duct component tubing at temper } \\
\text { point and after final draw. Calculate } \\
\text { percentage cold work for each lot using } \\
\text { Equation } 1 \text {. }\end{array}$ & \\
\hline 17 . & Lotting & 3.7 .2 & Each duct tube & Supplier's records. & \\
\hline 18. & Identification & 3.7 .3 & Each duct tube & $\begin{array}{l}\text { Visual examination for identification } \\
\text { number correctness. }\end{array}$ & \\
\hline 19. & Repair \& rework & 3.8 & Supplier certification & Supplier's records. & 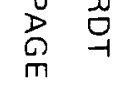 \\
\hline 20. & Archive sample & 3.9 & Supplier certification & Supplier's records. & 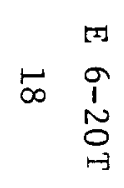 \\
\hline
\end{tabular}


controlled to the extent necessary to assure continued measurements of required accuracy giving due consideration to temperature, humidity, vibration, cleanliness, and other controllable factors affecting preciision measurement. When applicable, compensating corrections shall be applied to calibration results obtained in an environment which departs from standard conditions.

4.7.2 Calibration. Measuring and testing equipment shall be calibrated as specified in RDT F 3-2.

\subsection{Determination of Compliance and Data Recording for Inspection} and Test.

4.8.1 Tolerance Limit Interpretation. The following applies to al1 specified 1imits in this standard and Ordering Data.

a. Chemical Composition. For purposes of determining conformance with chemical composition requirements, an observed value or a calculated value shall be rounded off "to the nearest unit" in the last right-handed place of figures used in expressing the limiting value, in accordance with the rounding-off method of ASTM E 29.

b. Tensile Requirements. For purposed of determining comformance with tensile requirements, an observed value or a calculated value shall be rounded off to the nearest $100 \mathrm{psi}(689 \mathrm{kPa})$ for tensile strength and to the nearest 0.1 percent for elongation, in accordance with the rounding-off method of ASTM E 29.

c. Dimensional Requirements. The method for determining conformance with dimensional requirements shall be as specified in the Ordering Data (rounding off or absolute method as defined in ASTM E 29).

4.8.2 Equipment/Technique Accuracy. Unless otherwise required or approved by the purchaser, determinations shall be made with equipment or techniques reading accurately as specified in RDT F 3-15.

\section{PREPARATION FOR DELIVERY}

5.1 Packaging. Duct tubes shall be individually packaged in polyethylene and placed in a container constructed to ensure delivery of clean, straight, undamaged material in accordance with specific requirements of the Ordering Data and to maintain conformance with RDT F 7-2.

5.2 Shipping Containers. The complete description of shipping containers for duct tubes shall be submitted for approval before being used. 
5.3 Marking. Each packing box shall be legibly and conspicuously marked with the following data:

1. Purchase order number.

2. Name of supplier.

3. Lot number.

4. Number of pieces in container.

5. Gross and net weights.

6. Applicable drawing.

7. Duct number.

6. NOTES AND ORDERING DATA CHECKLIST

6.1 Intended Use. Duct tubes described by this standard are to be used in the fabrication of fuel, control rod, and other core component assemblies.

6.2 Ordering Data Checklist. The following technical and procurement data will be furnished by the purchaser. Any necessary data not furnished with the purchase document shall be requested from the purchaser before submitting a bid.

\section{Title}

1. Drawings

2. Other Documents

3. Chemica1 composition

4. Tensile properties

5. Hardness

6. Surface roughness

7. Surface maring

8. Tube dimensions

9. Cold work

10. Lotting

11. Identification

12. Archive samples

13. Quality assurance program requirements

14. Quality assurance documentation

15. Penetrant examination finished ducts

16. Dimensional requirements

17. Packaging
Refer to

Paragraph

2.6

2.7

3.1 .1

3.2 .1

3.2 .2

3.5 .2

3.5 .3

3.6

3.7 .1 (f)

3.7 .2

3.7 .3

3.9

4.1

4.2

4.5, Table 4, Item 6 4.8.1(c)

5.1 